\title{
Current Advances in Local Protein Synthesis and Synaptic Plasticity
}

\author{
Brad E. Pfeiffer and Kimberly M. Huber \\ Center for Basic Neuroscience, Department of Physiology, University of Texas Southwestern Medical Center, Dallas, Texas 75390
}

Local or dendritic protein synthesis is required for long-term functional synaptic change, such as long-term potentiation (LTP) and long-term depression (LTD). LTP and LTD both rely on similar signal transduction cascades, which regulate translation initiation. Current research indicates that the specificity by which new proteins participate in either LTP or LTD may be determined in part by specific RNA-binding proteins as well as activity-dependent capture.

Key words: LTP; ERK; LTD; protein synthesis; fragile X mental retardation protein; 4EBP

Persistent, activity-dependent changes at individual synapses are a mechanism by which the brain encodes and stores information. The most well established models for activity-dependent synaptic strengthening and weakening are long-term potentiation (LTP) and long-term depression (LTD), respectively. Both LTP and LTD display input, or synapse specificity, in which only the activated synapses express plasticity. How changes at individual synapses are maintained has been a subject of intense investigation. With the discovery of polyribosomes at or near synapses, it was hypothesized that neurotransmitter-stimulated synaptic or "local" protein synthesis may be a mechanism by which the protein complement of individual synapses is altered and long-term changes are maintained (Schuman et al., 2006). Support for this idea comes from studies that have demonstrated that LTP and LTD require new dendritic protein synthesis independent of transcription (Kang and Schuman, 1996; Huber et al., 2000; Cracco et al., 2005).

Because of the number of excellent reviews on local protein synthesis and synaptic plasticity in recent years (Kelleher et al., 2004b; Klann and Dever, 2004; Sutton and Schuman, 2005), this review will focus on recent advances in the field including the role of translation initiation and specific RNA-binding proteins in synaptic plasticity and the identity of candidate proteins in the stabilization of synaptic change.

\section{Local protein synthesis is required for the persistence of synaptic change}

Initial studies demonstrated a role for both translation and transcription in the maintenance of the late phase of LTP (L-LTP), and it was thought that the new proteins were derived from newly transcribed mRNA (for review, see Sutton and Schuman, 2005). However, it is now evident that the intermediate stages of L-LTP

Received April 27, 2006; revised May 28, 2006; accepted May 28, 2006.

Correspondence should be addressed to Dr. Kimberly M. Huber, Center for Basic Neuroscience, Utah Southwestern Medical Center, 5323 Harry Hines Boulevard, Dallas, TX 75390-9111. E-mail: Kimberly.Huber@UTSouthwestern.edu.

DOI:10.1523/JNEUROSCI.1797-06.2006

Copyright $\odot 2006$ Society for Neuroscience $\quad$ 0270-6474/06/267147-04\$15.00/0
(1-3 h) are maintained by new protein synthesis in dendrites independent of transcription (Kang and Schuman, 1996; Kelleher et al., 2004a; Cracco et al., 2005). Early LTP (E-LTP), which lasts $\sim 1 \mathrm{~h}$, is often induced with a single episode of highfrequency stimulation or tetanus and is mediated by posttranslational modifications of existing proteins. Transcriptiondependent forms of L-LTP $(>4 \mathrm{~h})$ are recruited by repeated spaced tetani (Banko et al., 2005), but this is not essential to observe the translation-dependent component of L-LTP (Raymond et al., 2000; Pang et al., 2004; Cracco et al., 2005). Likewise, at Aplysia californica sensory-motor neuron synapses, the conversion of a short-term to long-term facilitation (LTF) occurs with repeated stimuli and requires transcription and protein synthesis (Kandel, 2001). Although E-LTP and L-LTP both require NMDA receptor activation, $\mathrm{BDNF}, \mathrm{D}_{1} / \mathrm{D}_{5}$ dopamine receptors, and group 1 metabotropic glutamate receptors (mGluRs) are specifically implicated in generation of the protein synthesisdependent phase (for review, see Sutton and Schuman, 2005). Consistent with this observation, $\mathrm{BDNF}, \mathrm{mGluR}$, and $\mathrm{D}_{1} / \mathrm{D}_{5}$ receptor agonists stimulate protein synthesis in dendrites (Aakalu et al., 2001; Job and Eberwine, 2001; Smith et al., 2005).

The findings that long-term synaptic weakening or LTD requires dendritic protein synthesis indicate that new proteins maintain synaptic change regardless of the polarity. Activation of group $1 \mathrm{mGluRs}$ with either synaptic stimulation or the selective agonist $R, S$-dihydroxyphenylglycine (DHPG) induces LTD (mGluR-LTD) in hippocampal area CA1 and cerebellar Purkinje neurons that requires rapid synthesis of proteins, within minutes (Huber et al., 2000; Karachot et al., 2001). There is also evidence for a late phase of LTD (L-LTD) induced by activation of NMDA and $\mathrm{D}_{1} / \mathrm{D}_{5}$ dopamine receptors that does not require new proteins until 2-3 h after induction (Manahan-Vaughan et al., 2000; Sajikumar and Frey, 2003).

\section{New proteins regulate trafficking of ionotropic glutamate receptors}

Current evidence indicates that newly synthesized proteins maintain LTP and LTD through regulation of ionotropic glutamate receptor trafficking. DHPG treatment of cultured hippocampal 


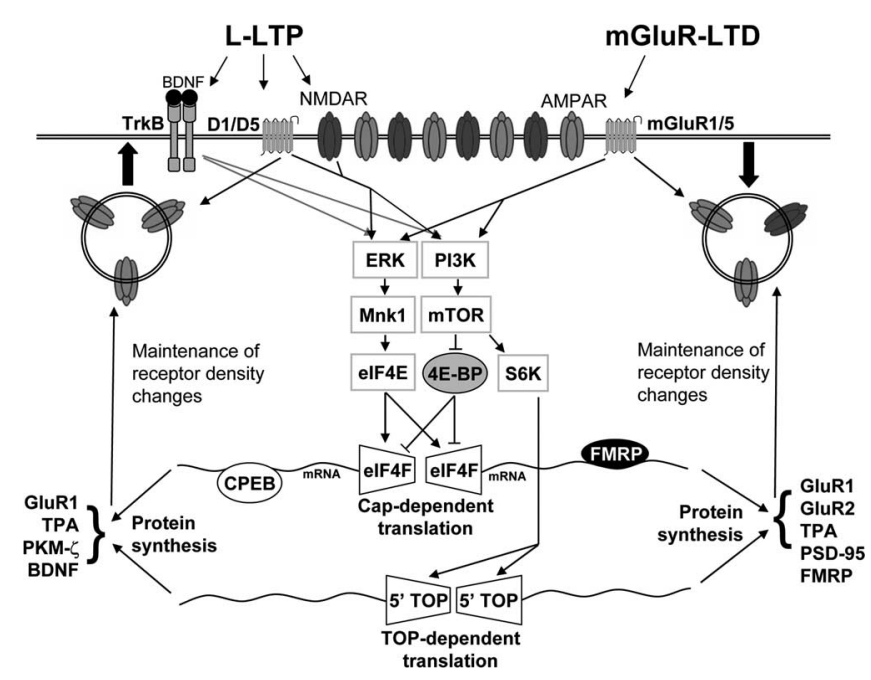

Figure 1. Convergence and divergence of mechanisms for protein synthesis-dependent LTP and LTD. Protein synthesis-dependent LTP (L-LTP) and mGluR-LTD activate and use similar, if not identical, pathways. To simplify, not all protein synthesis regulatory pathways are included, and second-messenger pathways upstream of ERK and PI3 kinase (PI3K) are omitted. Coactivation of NMDARs and dopamine $D_{1} / D_{5}$ receptors initiates the insertion of glutamate receptors to the synaptic surface and stimulates both ERK and PI3 kinase. Alternatively, agonists of $\mathrm{mGluR} 1 / 5$ receptors initiate the internalization of glutamate receptors but similarly activate the ERK and PI3 kinase pathways. L-LTP- and mGluR-LTD-inducing stimuli phosphorylate ERK, Mnk1, and elF4E and stimulate elF4F initiation complex assembly. Activated PI3 kinase phosphorylates $\mathrm{mTOR}$, which in turn phosphorylates and inactivates the negative regulator of capdependent translation initiation, 4EBP, thereby enhancing translation initiation. Activated mTOR additionally phosphorylates and activates $56 \mathrm{~K}$ (ribosomal $\$ 6$ kinase), which leads to increased TOP ( $5^{\prime}$ terminal oligopyrimidine tract)-dependent translation. Proteins translated in response to synaptic activity may facilitate or maintain alterations in surface receptor number, synapse size, and/or synapse number. A few selected proteins, the synthesis of which have been demonstrated or are required for protein synthesis-dependent plasticity by the two different stimulation paradigms, are listed.

neurons or slices induces a rapid endocytosis of postsynaptic ionotropic glutamate receptors [both AMPA receptors (AMPARs) and NMDA receptors (NMDARs)] that results in a decrease in surface receptor number and a decrease in the frequency of miniature EPSCs (mEPSCs) (Snyder et al., 2001; Xiao et al., 2001; Nosyreva and Huber, 2005). Initial endocytosis of AMPARs and NMDARs is independent of translation, but persistent decreases in surface expression require new proteins (Snyder et al., 2001; Nosyreva and Huber, 2005). The removal of postsynaptic AMPAR and NMDARs may lead to structural changes, such as dendritic spine elongation, which is also initiated by mGluR-stimulated protein synthesis (Vanderklish and Edelman, 2002).

In contrast, AMPAR insertion is stimulated by dopamine $\mathrm{D}_{1} / \mathrm{D}_{5}$ receptor-directed protein synthesis. $\mathrm{D}_{1} / \mathrm{D}_{5}$ activation stimulates dendritic synthesis of the GluR1 subunit of AMPARs, which results in a rapid increase in GluR1 surface expression (15 min) and an increase in mEPSC frequency (Smith et al., 2005). Therefore, newly synthesized proteins may maintain LTP and LTD by regulation of AMPAR trafficking or stabilization of structural changes that maintain receptor density at the synapse (Fig. 1).

Thus, dendritic protein synthesis functions to maintain both LTP and LTD. At what level is the specificity for synthesizing "LTP" or "LTD" proteins determined? Distinct patterns of synaptic activity may regulate distinct signaling cascades, differentially regulate translation machinery, or stimulate different RNAbinding proteins, which in turn target specific mRNAs for translation (Fig. 1). Alternatively, when translation is stimulated in dendrites, both LTP and LTD proteins may be synthesized simultaneously, and the specific pattern of synaptic stimulation may determine which proteins are used or "captured" (Kelleher et al., 2004b; Sajikumar and Frey, 2004). As described below, recent evidence suggests that aspects of both of these hypotheses may be correct.

\section{Translation initiation is implicated in LTP and LTD}

New evidence indicates that LTP and mGluR-LTD both regulate cap-dependent translation initiation and in turn are affected by manipulations of translation initiation machinery. NMDA treatment, E-LTP-inducing, and L-LTP-inducing protocols increase phosphorylation of Mnk1, eIF4E, 4EBP, and p70 S6 kinase and stimulate formation of the translation initiation (eIF4F) complex, all of which function to enhance translation initiation and the global translation rate (Banko et al., 2004, 2005; Kelleher et al., 2004a; Klann and Dever, 2004; Wells, 2006). Interestingly, DHPG treatment, which leads to mGluR-LTD, also results in phosphorylation of Mnk1, eIF4E, and 4EBP and stimulates eIF4F complex formation (Banko et al., 2006). In both LTP and LTD paradigms, Mnk1 and eIF4E phosphorylation depends on extracellular signal-regulated kinase (ERK) (Banko et al., 2004, 2005; Kelleher et al., 2004a). During mGluR-LTD, phosphatidylinositol-3 kinase (PI3 kinase) and mammalian target of rapamycin (mTOR) stimulate phosphorylation of eIF4Ebinding protein (4EBP), which is thought to gate eIF4E phosphorylation by ERK (Banko et al., 2006). Consistent with these biochemical findings, inhibition of PI3 kinase, mTOR, or ERK prevents protein synthesis-dependent LTP and mGluR-LTD (Tang et al., 2002; Gallagher et al., 2004; Hou and Klann, 2004; Kelleher et al., 2004a) (Fig. 1).

Recent studies demonstrate that genetic deletion of two suppressors of translation initiation, 4EBP2 and an eIF2a kinase, GCN2, similarly affect LTP and hippocampal-dependent memory (Banko et al., 2005; Costa-Mattioli et al., 2005). A single tetanus, which elicits only E-LTP in wild-type (WT) mice, results in a translation-dependent L-LTP in 4EBP2 and GCN2 knockout $(\mathrm{KO})$ mice, suggesting that the threshold for L-LTP is reduced. mGluR-LTD is also enhanced in the 4EBP2 knock-out mice (Banko et al., 2006). Surprisingly, spaced trains of $100 \mathrm{~Hz}$ stimulation, which elicit L-LTP in WT mice, cause little or no potentiation in mutant mice. As a result, both of these $\mathrm{KO}$ mice lines show a deficit in hippocampal-dependent memory tasks. The reduced L-LTP in response to space trains could be attributable to the elevated level of eIF4F initiation complexes formed in the absence of 4EBP and nonselective translation of mRNAs or repressors of LTP (Banko et al., 2005; Costa-Mattioli et al., 2005).

\section{RNA-binding proteins differentially regulate LTP and mGluR-LTD}

As highlighted in the accompanying review by Wells (2006), translation of specific mRNAs can be regulated by RNA-binding proteins. Recent studies have demonstrated a role for cytoplasmic polyadenylation element-binding protein (CPEB) and Fragile $\mathrm{X}$ mental retardation protein (FMRP) in LTP and mGluRLTD, respectively (Huber et al., 2002; Alarcon et al., 2004). CPEB binds to specific $3^{\prime}$ CPE sequences and at a basal state is thought to suppress translation of its mRNA targets. In response to extracellular stimuli, CPEB acts to facilitate polyadenylation and translation initiation by recruitment of PABP (polyA-binding protein) and eIF4G, respectively (Wells, 2006). Genetic deletion of one isoform of CPEB, CPEB1, resulted in a deficit in some, but 
not all, forms of protein synthesis-dependent LTP, suggesting that CPEB1-regulated polyadenylation of mRNAs contributes to the synthesis of proteins required for LTP (Alarcon et al., 2004). Likewise, downregulation of CPEB in Aplysia sensory neurons blocks LTF (Si et al., 2003). These results suggest that CPEB may specifically regulate proteins required for synaptic strengthening.

Like CPEB, FMRP is an RNA-binding protein that may suppress translation of its mRNA targets as well as act as a switch to stimulate protein synthesis in response to extracellular signals (Todd et al., 2003; Weiler et al., 2004; Grossman et al., 2006). Interestingly, the mRNA for FMRP is present in dendrites, and FMRP is synthesized in response to mGluR activation (Weiler et al., 1997; Antar et al., 2004). FMRP, in turn, regulates mGluRLTD. In mice lacking FMRP (Fmr1 KO mice), mGluR-LTD is enhanced and does not require new protein synthesis (Huber et al., 2002; Koekkoek et al., 2005; Nosyreva and Huber, 2006). This result suggests in the absence of FMRP there is an uncoupling of synaptic protein synthesis from activity as well as an abundance of proteins that maintain LTD without new synthesis. Although NMDAR-dependent LTP and LTD are unaffected in the hippocampus of Fmr1 KO mice (Godfraind et al., 1996; Huber et al., 2002), LTP in the amygdala and neocortex is absent (Li et al., 2002; Larson et al., 2005; Zhao et al., 2005). It is unclear whether this is caused by a deficit in a protein synthesis-dependent component of LTP. In the hippocampus, however, current data indicate that CPEB and FMRP may each specifically regulate the synthesis of proteins for L-LTP and mGluR-LTD, respectively.

\section{Local protein synthesis and synaptic tagging}

Frey and Morris (1997) observed that L-LTP induction at a subset of synapses stimulated the synthesis of new proteins that could be subsequently captured at a second independent set of synapses by a single tetanus, converting E-LTP to L-LTP (Frey and Morris, 1997). They hypothesized that a single tetanus generates a synaptic "tag" that mediates the capture of recently translated proteins, termed plasticity-related proteins (PRPs), from the soma or elsewhere in the dendrite. Similarly, proteins induced by prior L-LTD can be captured by E-LTD stimuli at independent synapses (Sajikumar and Frey, 2004). Surprisingly, there is evidence for what has been termed "cross-tagging" by L-LTD and L-LTP (Sajikumar and Frey, 2004). That is, E-LTP can be consolidated to L-LTP by the capture of proteins generated by previous L-LTD-inducing stimulation, and vice versa. This raises the intriguing possibility that the same proteins are synthesized in response to either L-LTP- or L-LTD-inducing stimuli and the synaptic tag determines the direction of synaptic change consolidated.

\section{Candidate PRPs}

The PRPs for LTP and LTD may be the same or similar proteins and simply function to stabilize synaptic changes initiated by E-LTP and E-LTD induction. Recent evidence indicates there are different PRPs for LTP and LTD. Protein kinase $\mathrm{M} \zeta(\mathrm{PKM} \zeta)$ is a constitutively active isoform of PKC and is induced by L-LTPinducing stimulation, and its activity is required for the maintenance of L-LTP but not L-LTD (Sajikumar et al., 2005). These results suggest that PKM $\zeta$ is a specific PRP for L-LTP. Other recent work demonstrates that exogenous application of BDNF is sufficient to maintain L-LTP in the presence of protein synthesis inhibitors, suggesting that BDNF is the only essential PRP (Pang et al., 2004). There is much less known about the PRPs for LTD. A number of studies have demonstrated synthesis of proteins with mGluR activation (DHPG), such as GluR1, GluR2, TPA (tissue plasminogen activator), and PSD-95 (postsynaptic density-95), but the role of these proteins in mGluR-facilitated LTP or mGluR-LTD is unknown (Kacharmina et al., 2000; Todd et al., 2003; Ju et al., 2004; Shin et al., 2004). The fact that all of these proteins are implicated in LTP maintenance suggests that, in addition to inducing LTD, DHPG stimulates the synthesis of proteins required for both LTP and LTD, lending support to the notion of selective capture (Kelleher et al., 2004b; Sajikumar and Frey, 2004).

\section{Summary and perspectives}

It is well established that new proteins are required to maintain the persistence of synaptic strengthening and weakening. Interestingly, similar signal transduction cascades are used to activate translation initiation by both LTP- and LTD-inducing stimulation. New data indicate that RNA-binding proteins and capture of new proteins contribute to the specificity of long-term synaptic change (Fig. 1). Because FMRP is implicated in human mental retardation, this suggests that misregulation of protein synthesisdependent plasticity contributes to human cognitive function and neurological disease (Bear et al., 2004; Koekkoek et al., 2005).

\section{References}

Aakalu G, Smith WB, Nguyen N, Jiang C, Schuman EM (2001) Dynamic visualization of local protein synthesis in hippocampal neurons. Neuron 30:489-502.

Alarcon JM, Hodgman R, Theis M, Huang YS, Kandel ER, Richter JD (2004) Selective modulation of some forms of Schaffer collateral-CA1 synaptic plasticity in mice with a disruption of the CPEB-1 gene. Learn Mem 11:318-327.

Antar LN, Afroz R, Dictenberg JB, Carroll RC, Bassell GJ (2004) Metabotropic glutamate receptor activation regulates Fragile $\mathrm{X}$ mental retardation protein and FMR1 mRNA localization differentially in dendrites and at synapses. J Neurosci 24:2648-2655.

Banko JL, Hou L, Klann E (2004) NMDA receptor activation results in PKA- and ERK-dependent Mnk1 activation and increased eIF4E phosphorylation in hippocampal area CA1. J Neurochem 91:462-470.

Banko JL, Poulin F, Hou L, DeMaria CT, Sonenberg N, Klann E (2005) The translation repressor 4E-BP2 is critical for eIF4F complex formation, synaptic plasticity, and memory in the hippocampus. J Neurosci 25:9581-9590.

Banko JL, Hou L, Poulin F, Sonenberg N, Klann E (2006) Regulation of eukaryotic initiation factor $4 \mathrm{E}$ by converging signaling pathways during metabotropic glutamate receptor-dependent long-term depression. J Neurosci 26:2167-2173.

Bear MF, Huber KM, Warren ST (2004) The mGluR theory of Fragile X mental retardation. Trends Neurosci 27:370-377.

Costa-Mattioli M, Gobert D, Harding H, Herdy B, Azzi M, Bruno M, Bidinosti M, Ben Mamou C, Marcinkiewicz E, Yoshida M, Imataka H, Cuello AC, Seidah N, Sossin W, Lacaille JC, Ron D, Nader K, Sonenberg N (2005) Translational control of hippocampal synaptic plasticity and memory by the eIF2alpha kinase GCN2. Nature 436:1166-1173.

Cracco JB, Serrano P, Moskowitz SI, Bergold PJ, Sacktor TC (2005) Protein synthesis-dependent LTP in isolated dendrites of CA1 pyramidal cells. Hippocampus 15:551-556.

Frey U, Morris RG (1997) Synaptic tagging and long-term potentiation. Nature 385:533-536.

Gallagher SM, Daly CA, Bear MF, Huber KM (2004) Extracellular signalregulated protein kinase activation is required for metabotropic glutamate receptor-dependent long-term depression in hippocampal area CA1. J Neurosci 24:4859-4864.

Godfraind JM, Reyniers E, De Boulle K, D’Hooge R, De Deyn PP, Bakker CE, Oostra BA, Kooy RF, Willems PJ (1996) Long-term potentiation in the hippocampus of Fragile X knockout mice. Am J Med Genet 64:246-251.

Grossman AW, Aldridge GM, Weiler IJ, Greenough WT (2006) Local protein synthesis and spine morphogenesis: Fragile $\mathrm{X}$ syndrome and beyond. J Neurosci 26:7151-7155.

Hou L, Klann E (2004) Activation of the phosphoinositide 3-kinase-Aktmammalian target of rapamycin signaling pathway is required for 
metabotropic glutamate receptor-dependent long-term depression. J Neurosci 24:6352-6361.

Huber KM, Kayser MS, Bear MF (2000) Role for rapid dendritic protein synthesis in hippocampal mGluR-dependent LTD. Science 288:1254-1257.

Huber KM, Gallagher SM, Warren ST, Bear MF (2002) Altered synaptic plasticity in a mouse model of Fragile-X mental retardation. Proc Natl Acad Sci USA 99:7746-7750.

Job C, Eberwine J (2001) Identification of sites for exponential translation in living dendrites. Proc Natl Acad Sci USA 98:13037-13042.

Ju W, Morishita W, Tsui J, Gaietta G, Deerinck TJ, Adams SR, Garner CC, Tsien RY, Ellisman MH, Malenka RC (2004) Activity-dependent regulation of dendritic synthesis and trafficking of AMPA receptors. Nat Neurosci 7:244-253.

Kacharmina JE, Job C, Crino P, Eberwine J (2000) Stimulation of glutamate receptor protein synthesis and membrane insertion within isolated neuronal dendrites. Proc Natl Acad Sci USA 97:11545-11550.

Kandel ER (2001) The molecular biology of memory storage: a dialogue between genes and synapses. Science 294:1030-1038.

Kang H, Schuman EM (1996) A requirement for local protein synthesis in neurotrophin-induced hippocampal synaptic plasticity. Science 273:1402-1406.

Karachot L, Shirai Y, Vigot R, Yamamori T, Ito M (2001) Induction of longterm depression in cerebellar Purkinje cells requires a rapidly turned over protein. J Neurophysiol 86:280-289.

Kelleher III RJ, Govindarajan A, Jung HY, Kang H, Tonegawa S (2004a) Translational control by MAPK signaling in long-term synaptic plasticity and memory. Cell 116:467-479.

Kelleher III RJ, Govindarajan A, Tonegawa S (2004b) Translational regulatory mechanisms in persistent forms of synaptic plasticity. Neuron 44:59-73.

Klann E, Dever TE (2004) Biochemical mechanisms for translational regulation in synaptic plasticity. Nat Rev Neurosci 5:931-942.

Koekkoek SK, Yamaguchi K, Milojkovic BA, Dortland BR, Ruigrok TJ, Maex R, De Graaf W, Smit AE, VanderWerf F, Bakker CE, Willemsen R, Ikeda T, Kakizawa S, Onodera K, Nelson DL, Mientjes E, Joosten M, De Schutter E, Oostra BA, Ito M, De Zeeuw CI (2005) Deletion of FMR1 in Purkinje cells enhances parallel fiber LTD, enlarges spines, and attenuates cerebellar eyelid conditioning in Fragile X syndrome. Neuron 47:339-352.

Larson J, Jessen RE, Kim D, Fine AK, du Hoffmann J (2005) Age-dependent and selective impairment of long-term potentiation in the anterior piriform cortex of mice lacking the Fragile X mental retardation protein. J Neurosci 25:9460-9469.

Li J, Pelletier MR, Perez Velazquez JL, Carlen PL (2002) Reduced cortical synaptic plasticity and GluR1 expression associated with Fragile X mental retardation protein deficiency. Mol Cell Neurosci 19:138-151.

Manahan-Vaughan D, Kulla A, Frey JU (2000) Requirement of translation but not transcription for the maintenance of long-term depression in the CA1 region of freely moving rats. J Neurosci 20:8572-8576.

Nosyreva ED, Huber KM (2005) Developmental switch in synaptic mechanisms of hippocampal metabotropic glutamate receptor-dependent longterm depression. J Neurosci 25:2992-3001.

Nosyreva ED, Huber KM (2006) Metabotropic receptor-dependent longterm depression persists in the absence of protein synthesis in the mouse model of Fragile X syndrome. J Neurophysiol 95:3291-3295.

Pang PT, Teng HK, Zaitsev E, Woo NT, Sakata K, Zhen S, Teng KK, Yung
WH, Hempstead BL, Lu B (2004) Cleavage of proBDNF by tPA/plasmin is essential for long-term hippocampal plasticity. Science 306:487-491.

Raymond CR, Thompson VL, Tate WP, Abraham WC (2000) Metabotropic glutamate receptors trigger homosynaptic protein synthesis to prolong long-term potentiation. J Neurosci 20:969-976.

Sajikumar S, Frey JU (2003) Anisomycin inhibits the late maintenance of long-term depression in rat hippocampal slices in vitro. Neurosci Lett 338:147-150.

Sajikumar S, Frey JU (2004) Late-associativity, synaptic tagging, and the role of dopamine during LTP and LTD. Neurobiol Learn Mem 82:12-25.

Sajikumar S, Navakkode S, Sacktor TC, Frey JU (2005) Synaptic tagging and cross-tagging: the role of protein kinase $\mathrm{M} \zeta$ in maintaining long-term potentiation but not long-term depression. J Neurosci 25:5750-5756.

Schuman EM, Dynes J, Steward O (2006) Synaptic regulation of translation of dendritic mRNAs. J Neurosci 26:7143-7146.

Shin CY, Kundel M, Wells DG (2004) Rapid, activity-induced increase in tissue plasminogen activator is mediated by metabotropic glutamate receptor-dependent mRNA translation. J Neurosci 24:9425-9433.

Si K, Giustetto M, Etkin A, Hsu R, Janisiewicz AM, Miniaci MC, Kim JH, Zhu H, Kandel ER (2003) A neuronal isoform of CPEB regulates local protein synthesis and stabilizes synapse-specific long-term facilitation in Aplysia. Cell 115:893-904.

Smith WB, Starck SR, Roberts RW, Schuman EM (2005) Dopaminergic stimulation of local protein synthesis enhances surface expression of GluR1 and synaptic transmission in hippocampal neurons. Neuron 45:765-779.

Snyder EM, Philpot BD, Huber KM, Dong X, Fallon JR, Bear MF (2001) Internalization of ionotropic glutamate receptors in response to mGluR activation. Nat Neurosci 4:1079-1085.

Sutton MA, Schuman EM (2005) Local translational control in dendrites and its role in long-term synaptic plasticity. J Neurobiol 64:116-131.

Tang SJ, Reis G, Kang H, Gingras AC, Sonenberg N, Schuman EM (2002) A rapamycin-sensitive signaling pathway contributes to long-term synaptic plasticity in the hippocampus. Proc Natl Acad Sci USA 99:467-472.

Todd PK, Mack KJ, Malter JS (2003) The Fragile X mental retardation protein is required for type-I metabotropic glutamate receptor-dependent translation of PSD-95. Proc Natl Acad Sci USA 100:14374-14378.

Vanderklish PW, Edelman GM (2002) Dendritic spines elongate after stimulation of group 1 metabotropic glutamate receptors in cultured hippocampal neurons. Proc Natl Acad Sci USA 99:1639-1644.

Weiler IJ, Irwin SA, Klintsova AY, Spencer CM, Brazelton AD, Miyashiro K, Comery TA, Patel B, Eberwine J, Greenough WT (1997) Fragile X mental retardation protein is translated near synapses in response to neurotransmitter activation. Proc Natl Acad Sci USA 94:5395-5400.

Weiler IJ, Spangler CC, Klintsova AY, Grossman AW, Kim SH, BertainaAnglade V, Khaliq H, de Vries FE, Lambers FA, Hatia F, Base CK, Greenough WT (2004) Fragile X mental retardation protein is necessary for neurotransmitter-activated protein translation at synapses. Proc Natl Acad Sci USA 101:17504-17509.

Wells DG (2006) RNA-binding proteins: a lesson in repression. J Neurosci 26:7135-7138.

Xiao MY, Zhou Q, Nicoll RA (2001) Metabotropic glutamate receptor activation causes a rapid redistribution of AMPA receptors. Neuropharmacology 41:664-671.

Zhao MG, Toyoda H, Ko SW, Ding HK, Wu LJ, Zhuo M (2005) Deficits in trace fear memory and long-term potentiation in a mouse model for Fragile X syndrome. J Neurosci 25:7385-7392. 